\title{
The effect of seasonality on the structure of rotifers in a black-water shallow lake in Central Amazonia
}

\author{
CLARICE C. NOVA ${ }^{1}$, VANESSA G. LOPES ${ }^{2}$, LEONARDO COIMBRA E SOUZA ${ }^{3}$, \\ BETINA KOZLOWSKY-SUZUKI ${ }^{4}$, TALITA A.A. PEREIRA ${ }^{5}$ and CHRISTINA W.C. BRANCO ${ }^{3}$ \\ ${ }^{1}$ Departamento de Ecologia, Instituto de Biologia, Universidade Federal do Rio de Janeiro/ UFRJ, \\ Av. Carlos Chagas Filho, 373, 21940-901 Rio de Janeiro, RJ, Brasil \\ ${ }^{2}$ Departamento de Ecologia e Evolução, Instituto de Ciências Biológicas, \\ Universidade Federal de Goiás /UFG, Campus II, 74001-970 Goiânia, GO, Brasil \\ ${ }^{3}$ Departamento de Zoologia, Instituto de Biociências, Universidade Federal do Estado do Rio de Janeiro/ UNIRIO, \\ Av. Pasteur, 458, 22290-240 Rio de Janeiro, RJ, Brasil \\ ${ }^{4}$ Departamento de Ecologia e Recursos Marinhos, Instituto de Biociências, \\ Universidade Federal do Estado do Rio de Janeiro/ UNIRIO, Av. Pasteur, 458, 22290-240 Rio de Janeiro, RJ, Brasil \\ ${ }^{5}$ Centro de Pesquisas e Desenvolvimento Leopoldo Américo Miguez de Mello, Petrobras, \\ Av. Horácio Macedo, 950, 21941-915 Rio de Janeiro, RJ, Brasil
}

Manuscript received on August 8, 2013; accepted for publication on November 26, 2013

\begin{abstract}
Rotifers have often been used as indicators of sudden changes in physical and chemical features of the aquatic environment. Such features vary greatly during flood pulse events in small lakes connected to major floodplains. However, few are the studies that investigate the consequences of the flood pulse in rotifer species composition, abundance, richness and diversity, especially in Amazonian lakes. We analyzed samples from a small blackwater lake of an "igarapé" connected permanently to the Negro river, in Central Amazonia. Samples were taken twice a year for two years, comprising flooding and receding periods of the flood pulse. Rotifer abundance increased significantly after draught events, and electrical conductivity and turbidity were intrinsically related to such variation. Species composition also changed from flooding to receding periods. Some taxa, such as Brachionus zahniseri reductus and Lecane remanei were restricted to receding periods, while Brachionus zahniseri, Brachionus gillardi and Lecane proiecta were only present during flooding. A shift in the composition of rotifer families was observed from one period to another, showing the effect of renewing waters of the flood pulse. These results suggest that the flood pulse acts as a driving force and stressing condition, considerably altering rotifer community dynamics, either changing species composition or decreasing abundance.
\end{abstract}

Key words: floodplain, flood pulse, "igarapé", Rotifera, zooplankton.

\section{INTRODUCTION}

The value of zooplankton as an indicator of ecological conditions stems from its position in the food web, between the top-down regulators (fish)

Correspondence to: Clarice Casa Nova

E-mail: casanova.cla@gmail.com and bottom-up factors (phytoplankton) (Jeppesen et al. 2011). Rotifers are a well-represented and important component of zooplankton in freshwaters (Nogrady et al. 1993), and due to their unique physiology, short life cycle and their multiple niches, they are considered refined sensors 
to monitor shifts in physical and chemical features of the water column.

Several studies have highlighted the potential of rotifers as indicators of environmental conditions such as trophic state, $\mathrm{pH}$ or salinity in both temperate and tropical aquatic ecosystems (e.g. Kuczynski 1987, Branco et al. 2000, 2002). Besides responding to shifts in physical and chemical conditions (e.g. Branco et al. 2005, Souza et al. 2011), the spatial and seasonal distribution of rotifers also indicate the intensity of biotic interactions such as competition and predation by vertebrates and invertebrates (Nogrady et al. 1993, Walsh et al. 2006).

Few studies have addressed ecological aspects of zooplankton communities and rotifer assemblages in small streams (called "igarapés") and their associated lakes in Central Amazonia. These 'igarapés', altogether, are remarkable in many ways: high content of dissolved humic substances, acid $\mathrm{pH}$, low electrical conductivity (8.4-15S.cm²) and low primary production (Sioli 1975, Brandorff and Andrade 1978, Walker 1981). Some studies on zooplankton of clearwater, blackwater and whitewater floodplain lakes should, however, be mentioned (e.g. Brandorff and Andrade 1978, Hardy 1980, Hardy et al. 1984, Brandorff and Hardy 2009).

Since these "igarapés" are part of a floodplain river system, they are subjected to variations in the water level - a phenomenon called flooding pulse, which can affect the dynamics of aquatic communities, causing shifts in species composition and diversity (Paidere 2009). Junk et al. 1989, identified the flood-pulse as being responsible for productivity and the existence of the entire Amazon river-floodplain system. Generally, the flood pulse, due to changes in the physical and chemical environment, affects the biota, which responds through morphological, anatomical, physiological adaptations, hence producing characteristic community structures (Junk et al. 1989).
The flood pulse itself is a seasonal driving force (Junk etal. 1989)and withinits distinctphases(flooding, flood, receding and draught) seasonal flooding allows aquatic organisms to redistribute themselves within the spatial mosaic of the river-floodplain (Rodríguez and Lewis Jr 1994, 1997). Gradually changing water level forces aquatic organisms of the shallow littoral zone to continually colonize new habitats (Arrington and Winemiller 2006).

Reviewing the art status of rotifer studies in natural environments of floodplains in South America, Aoyagui and Bonecker (2004) concluded that there were few studies addressing this group in spite of the vast and heterogeneous territorial extent, and the various floodplain environments not even explored. In Brazil, considering the variety and complexity of the several river basins and the presence of floodplain systems including numerous lakes (Carvalho et al. 2001), the knowledge on rotifer ecology in these aquatic ecosystems is relatively scarce.

This study evaluated the influence of flood pulses in the rotifers community of a small "igarapé" lake in the Rio Negro floodplain. Thus, the aim of this study was to associate rotifers species richness, density and diversity with changes caused by the flood-pulse and its influence in the physical and chemical variables. Furthermore, we also tried to observe spatial changes in the assemblage. We hypothesized that distinct phases of the flood pulse - in this case, flooding and receding periods - will strongly influence the rotifer assemblage structure, either increasing species richness, varying species composition or increasing diversity.

\section{MATERIALS AND METHODS}

\section{STUDY SITE AND ITS CHARACTERISTICS}

The studied "igarapé" lake belongs to the Negro river floodplain (Amazonia, Brazil) and it is located nearby the city of Manaus ( $\left.3^{\circ} 02^{\prime} 17.47^{\prime \prime S} 60^{\circ} 15^{\prime} 07.85^{\prime \prime} \mathrm{W}\right)$. This shallow waterbody is regionally named 
Lake Arrombado (LARR) and it is part of Tupé's Sustainable Development Reserve (Reserva de Desenvolvimento Sustentável - RDS Tupé). LARR (Figure 1) is a black-water shallow lake surrounded by native forest and is characterized by a high content of humic dissolved substances, as in most freshwater environments connected to the Rio Negro basin (Brandorff and Hardy 2009).

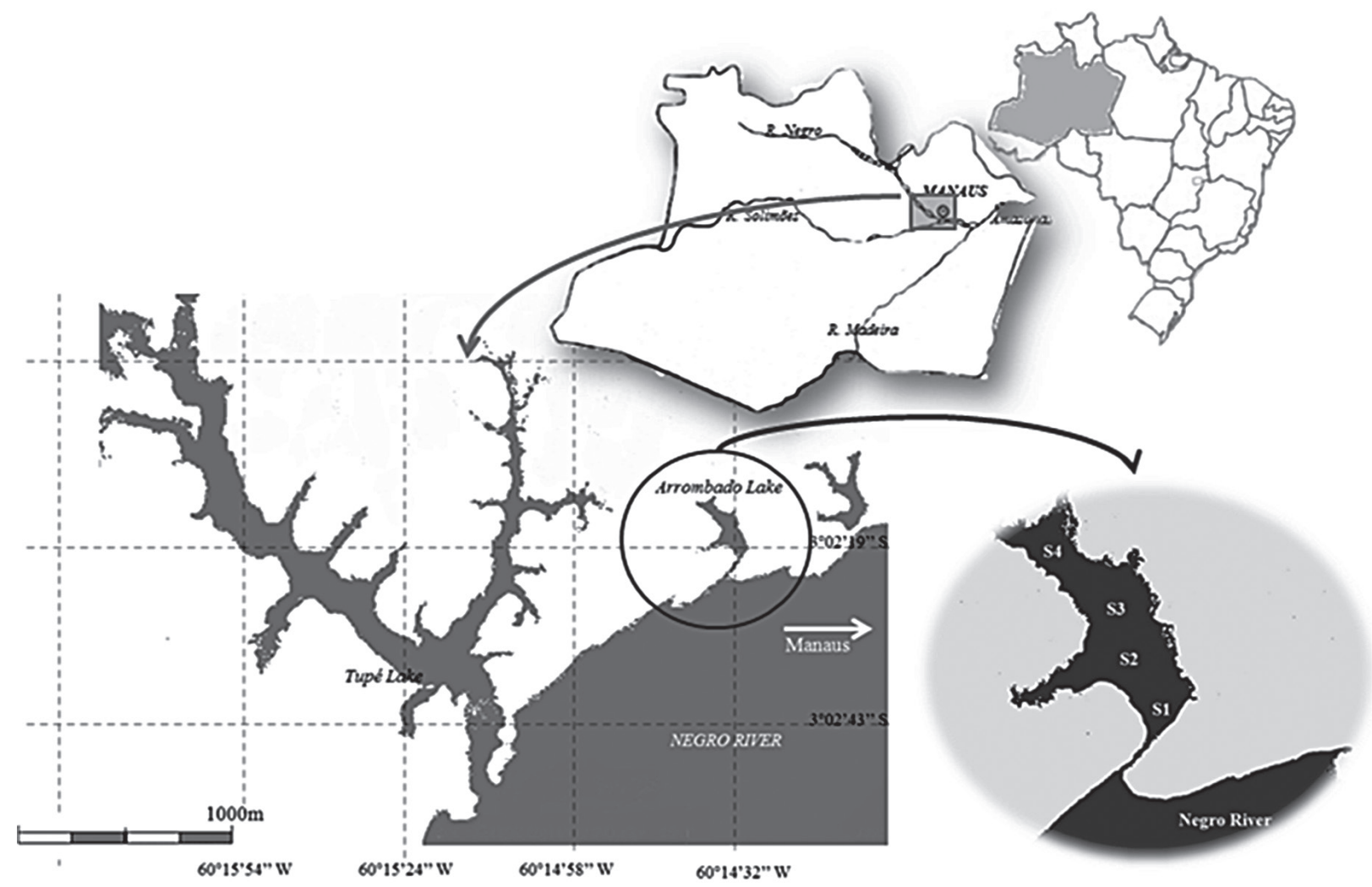

Figure 1 - Location of Arrombado Lake (LARR), Central Amazonia, Negro River Floodplain, Brazil. In detail, LARR and the sampling stations.

Nonetheless, during the study LARR had a permanent connection to the main river (Rio Negro) through the mouth within a sandbar, which is intermittent and, at low water level, only a narrow channel remains open to the river. Four sampling stations were determined comprising a gradient from the mouth of the lake to the inner part near the forest.

Station 1 - Located exactly at the connection channel of the lake and the main river.

Station 2 - First sampling station inside the lake.

Station 3 - Located in the middle of the lake, in an open area.
Station 4 - Located near the forest, a littoral sampling site. It is the station located farthest away from the sandbar.

SAMPLING

Sampling periods were chosen to match two distinct hydrological cycles of two consecutive flood pulses of the Negro River (AM). Samples were taken in two periods of falling waters (August of 2006 and 2007) and two periods of rising waters (March of 2007 and 2008). Sampling also matched periods of higher and lower rain precipitation of the two consecutive cycles.

Bucket filtration of $100 \mathrm{~L}$ of under-surface water using a $68 \mu \mathrm{m}$-mesh size net for zooplankton 
was performed in the field, and samples were immediately fixed with buffered formaldehyde in a $4 \%$ concentration. This sampling was done with two replicates for the quantitative zooplankton analysis. Horizontal hauls using a net of $68 \mu \mathrm{m}$-mesh size were done at each sampling point for qualitative analysis. Water temperature $\left({ }^{\circ} \mathrm{C}\right)$, dissolved oxygen (mg.L ${ }^{-1}$ ) and electric conductivity $\left(\mu \mathrm{S} . \mathrm{cm}^{-1}\right)$ were measured in all of the sampling stations using a multi-probe device (YSI-85 model). pH was determined with a $\mathrm{pH}$-meter (Thermo Scientific Orion $5^{\circledR}$ ). Depth was measured using a depthmeasurer and water transparency was measured using a Secchi disc depth.

\section{DATA ANALYSES}

Qualitative analyses of zooplankton were performed under an optical microscope integrated to microphotograph equipment used to optimize species recognition. Taxa identification was made using taxonomic studies performed by Koste (1978), Nogrady et al. (1993), Fernando (2002), Segers (2007). Quantitative samples were counted in a Sedgewick-Rafter counting cell. Species diversity (H') and evenness (J') were calculated using the Shannon-Wiener index - natural log.

Statistical analyses were also used to integrate biotic characteristics using Statistica 7.0 software package for Windows Vista and Windows 7. A factorial analysis of variance (f-ANOVA) was performed to elucidate possible interactions between the two categorical factors (different seasons and sampling stations) and check for significant statistical differences between biotic dependent variables. The significance level used was $\mathrm{P}<0.05$. All data were pre-tested for a normality fitting (Shapiro-Wilks test) and homocedasticity (Levenne's test). Variables which did not match such assumptions were either log-transformed or removed from $f$-ANOVA.

Canonical Correspondence Analysis (CCA) was used to assess the relationship between physical and chemical variables and abundance of frequent taxa. CCA was executed using $\mathrm{R}$ software. The CCA was performed using abundance data of species which had a $50 \%$ occurrence or higher, thus classified as frequent species (Gomes 1989). Such limiting 50\% tenet enables an overall look upon the effects of seasonality in the community. Data were $\log$ transformed $(\log \mathrm{x}+1)$ to satisfy a normality fitting. In R, the library used was Vegan (v. 2.0-1, compiled in $\mathrm{R}$ version 2.13.2) and Monte-Carlo hypothesis test was adjusted to 999 permutations.

\section{RESULTS}

\section{PHYSICAL AND CHEMICAL FACTORS}

Hydrological data from the Negro River were obtained from the Brazilian National Water Agency for the studied period (Figure 2), and confirmed that the samplings were performed during the flooding waters of 2006 and 2007 and receding waters of 2007 and 2008. The annual variation in water level of the Negro River was between 9 and $12 \mathrm{~m}$.

Total depth and electrical conductivity were higher in all of the sampling stations during falling waters. Additionally, water transparency was slightly lower in most sampling stations during this hydrological period, (Table I). The lowest concentration of dissolved oxygen occurred during the receding period of 2007, whereas the highest occurred during the same period of 2006. The highest water temperature was measured in falling waters of 2006 in all sampling stations while the lowest was recorded in the same period of the consecutive year (Aug 2007). On the other hand, $\mathrm{pH}$ was higher during the rising period of 2008 and lower during flooding of the previous year.

\section{ROTIFER SPECIES COMPOSITION AND ABUNDANCE}

Fifty-five rotifer species were identified, belonging to 15 taxonomical families (Table II). Monogononta rotifers accounted for most species ranked. Bdelloidea was treated as a gross taxonomic group due to difficulties involving specific identification. 
Brachionidae, Lecanidae and Trichocercidae were the most species-rich families - with 16, 10 and 5 species each, respectively. Higher values of species richness occurred during rising water period of 2008 in all sampling stations (Figure 3). During rising waters species richness peaked at

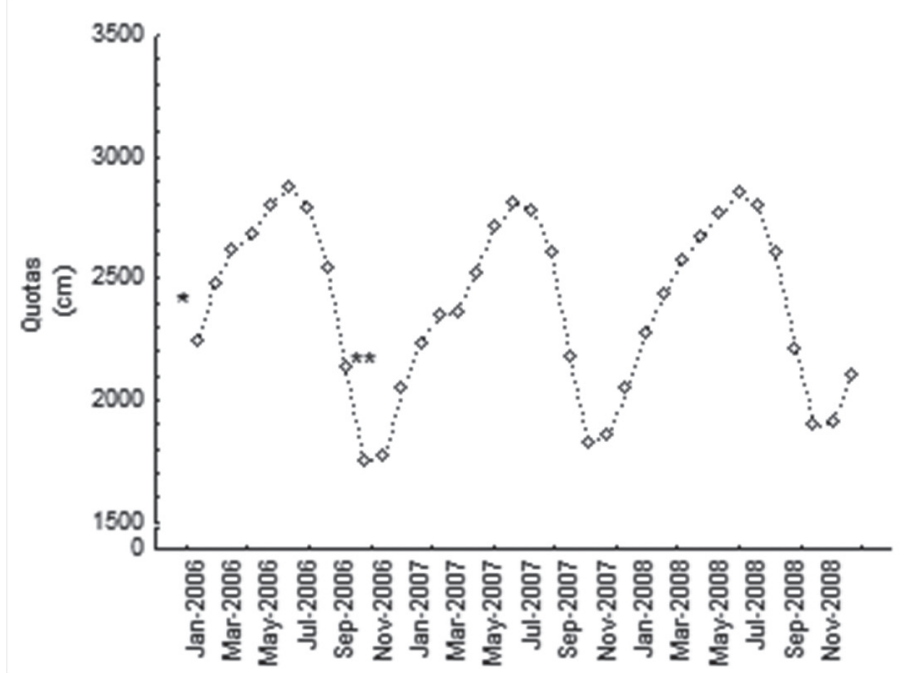

Figure 2 - Hydrological quotas (cm) of the Negro River floodplain during two consecutive years. (*) Indicates flooding period and (**) indicates receding water period. Source: Brazil's National Water Agency (ANA).

TABLE I

Physical and chemical variables from the Arrombado lake during receding (August 2006 and 2007) and flooding (March 2007 and 2008) periods. (n.o.) = Values not obtained. SD= standard deviation.

Means were calculated using the values of the four sampling stations.

\begin{tabular}{c|ccc|ccc|ccc|ccc}
\hline & \multicolumn{3}{|c|}{ August 2006 } & \multicolumn{3}{c|}{ March 2007 } & \multicolumn{3}{c}{ August 2007 } & \multicolumn{4}{c}{ March 2008 } \\
Variables & Mean & SD & Range & Mean & SD & Range & Mean & SD & Range & Mean & SD & Range \\
\hline $\begin{array}{c}\text { Conductivity } \\
(\mu \mathrm{S} / \mathrm{cm})\end{array}$ & 9.08 & 0.05 & $9.1-9.0$ & 5.00 & 0.2 & $5.3-4.9$ & 9.78 & 0.22 & $10.0-9.5$ & 7.33 & 0.15 & $7.5-7.2$ \\
$\begin{array}{c}\text { Transparency } \\
(\mathrm{m})\end{array}$ & 0.78 & 0.10 & $0.9-0.7$ & 1.05 & 0.1 & $1.1-1.4$ & 0.88 & 0.37 & $1.4-0.6$ & 0.91 & 0.12 & $1.0-0.8$ \\
$\begin{array}{c}\text { Dissolved } \\
\text { Oxygen }(\mathrm{mg} / \mathrm{L})\end{array}$ & 5.14 & 0.48 & $5.6-4.7$ & 3.92 & 0.11 & $4.1-3.8$ & 2.81 & 0.52 & $3.4-2.1$ & 4.23 & 0.43 & $4.6-3.6$ \\
$\begin{array}{c}\text { Temperature } \\
\left({ }^{\circ} \mathrm{C}\right)\end{array}$ & 30.05 & 0.37 & $30.3-29.5$ & 28.80 & 0.27 & $29-28.4$ & 28.75 & 0.06 & $28.8-28.7$ & 29.20 & 0.20 & $29.9-28.9$ \\
$\begin{array}{c}\text { Total depth } \\
\mathrm{pH}\end{array}$ & 3.60 & 0.55 & $4.0-3.0$ & 1.88 & 0.75 & $2.5-1.2$ & 3.91 & 0.64 & $4.8-3.0$ & 2.63 & 0.66 & $3.8-0.8$ \\
\hline & 4.99 & n.o. & n.o. & 4.58 & n.o. & n.o. & 4.68 & n.o. & n.o. & 5.42 & n.o. & n.o. \\
\hline
\end{tabular}

station 4. The most frequent families encountered were Brachionidae, Synchaetidae and Lecanidae. Thus, the most common species were Keratella americana, Polyarthra vulgaris and Lecane melini, which were present in all samples.

Rotifer density reached the highest values during flooding of 2008 in all sampling points (Figure 4). However, rotifer abundance peaked (64849 ind. $\mathrm{m}^{-3}$ ) at sampling station 2, during the receding water of the first hydrological cycle analyzed.
Rotifers were primarily dominated by Brachionidae with high densities of Brachionus zahniseri during the entire studied period. $B$. zahniseri and B. zahniseri var. reductus showed population shifts: the former dominated only during flooding whereas the latter dominated only during receding periods.

Lecanidae was mainly represented by Lecane melini in all stations. Lecane remanei was also important during the receding water period in all sampling stations. 
Table II

Taxonomic inventory of rotifers in LARR and species occurrence during two phases of the flood pulse (receding and flooding). Bold symbols summarizes occurrence in: $B=$ both phases; $R=$ receding; $F=$ flooding

ASPLANCNIDAE

Asplanchna sieboldi Gosse, $1850^{B}$

\section{BDELOIDEA}

Bdeloidea sp1. ${ }^{B}$

Bdeloidea sp2. ${ }^{B}$

\section{BRACHIONIDAE}

Anuraeopsis fissa Gosse, $1851^{\text {B }}$

Brachionus calyciflorus Pallas, $1766^{B}$

Brachionus caudatus Barrois \& Daday $1894^{F}$

Brachionus dolabratus Harring, $1915^{F}$

Brachionus gillardi Hauer, $1966^{F}$

Brachionus havanaensis Rousselet, $1911^{F}$

Brachionus mirus Daday, $1905^{F}$

Brachionus zahniseri Ahlstrom, $1934^{F}$

Brachionus zahniseri var. reductus Hauer, $1956^{R}$

Keratella americana Carlin, $1943^{B}$

Keratella cochlearis Gosse, $1851^{B}$

Macrochaetus sericus Gosse, $1867^{F}$

Notholca lamellifera Vassilijewa \& Kutikova, 1969 F

Platyas quadricornis Ehrenberg, $1832^{\text {B }}$

Platyonus patulus Müller, $1786^{R}$

Trichotria tetractis Ehrenberg, $1830^{F}$

\section{CONOCHILIDAE}

Conochilus coenobasis Skorikov, $1914^{B}$

\section{EUCHLANIDAE}

Dipleuchlanis propatula Gosse, $1886^{B}$

Euchlanis dilatata Ehrenberg, $1832^{F}$

\section{GASTROPODIDAE}

Gastropus sp. Imhof, $1898^{B}$

Ascomorpha saltans Bartsh, $1870^{R}$

\section{HEXARTHRIDAE}

Hexarthra sp. Schmarda, $1854^{F}$

\section{LECANIDAE}

Lecane bulla Gosse, $1886^{\text {B }}$

Lecane curvicornis Murray, $1913^{\text {B }}$

Lecane kuticowa Koste, $1972^{F}$

Lecane luna Müller, $1776^{R}$

Lecane lunaris Ehrenberg, $1832^{\text {B }}$

Lecane melini Thomasson, $1953^{B}$

Lecane papuana Murray, $1913^{F}$

Lecane proiecta Hauer, $1956^{F}$

Lecane quadridentata Ehrenberg, $1830^{R}$

Lecane remanei Hauer, $1964^{R}$

\section{LEPADELLIDAE}

Lepadella patella Müller, $1786^{F}$

Xenolepadella monodactyla Bérzins, $1960^{F}$

MYTILLINIDAE

Mytilina macrocera Jennings, $1894^{R}$

\section{NOTOMMATIDAE}

Cephalodella sp. Bory de St. Vincent, $1826^{F}$

Monommata sp. Bartsch, $1870^{F}$

\section{SYNCHAETIDAE}

Ploesoma truncatum Levander, $1894^{B}$

Polyarthra vulgaris Carlin, $1943^{\text {B }}$

Synchaeta oblonga Ehrenberg, $1832^{\text {в }}$

TESTUDINELLIDAE

Testudinella patina Hermann, $1783^{B}$

THRICOCERCIDAE

Trichocerca bicristata Gosse, $1887^{\text {в }}$

Trichocerca capucina Wierzejski \& Zacharias, $1893^{\text {B }}$

Trichocerca similis Wierzejski, $1893^{{ }^{B}}$

Trichocerca similis chatoni Wierzejski, $1893^{\text {B }}$

Trichocerca sp. Lamarck, $1801^{B}$

TRICHOSPHAERIDAE

Filinia longiseta Ehrenberg, $1834^{\text {B }}$ 


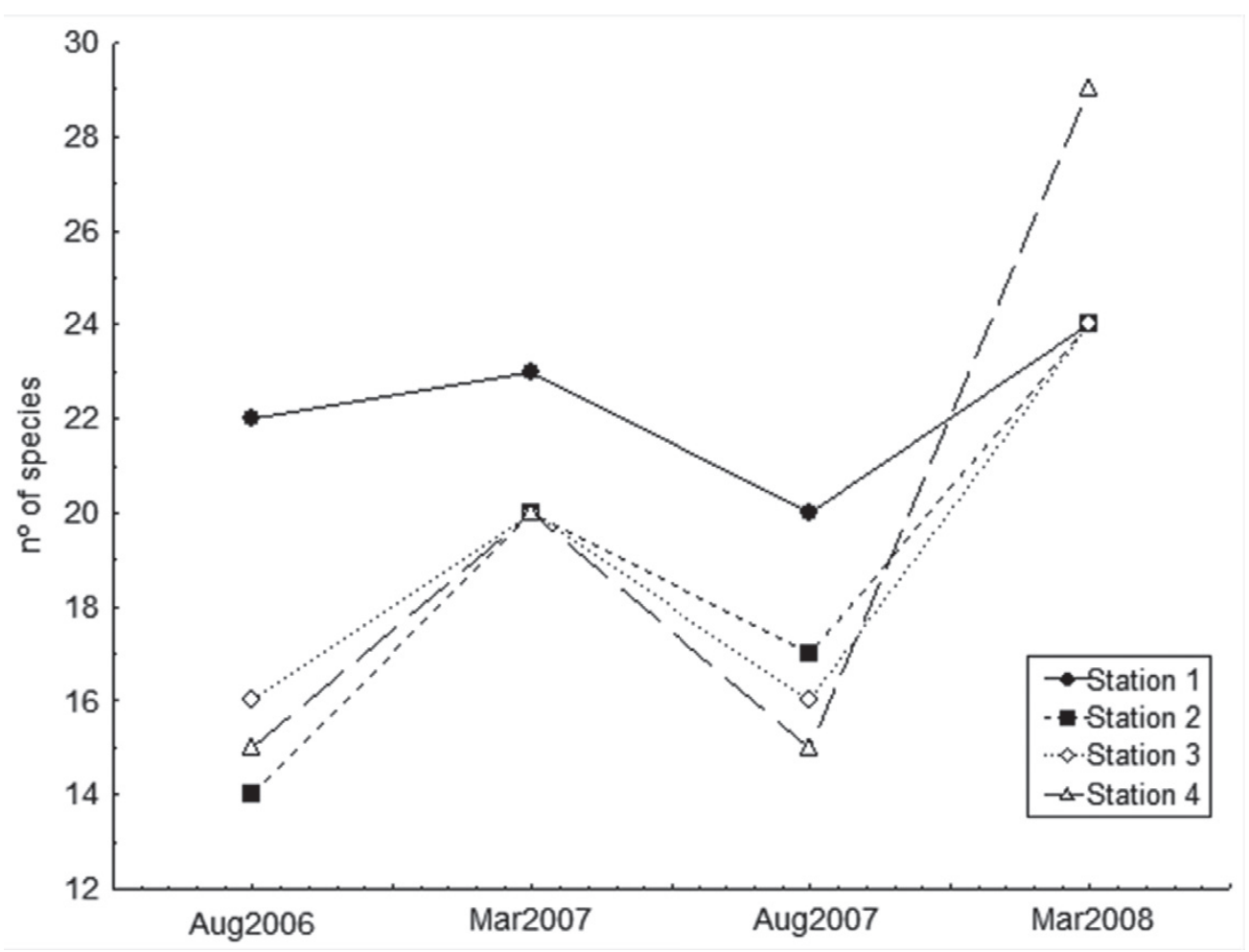

Figure 3 - Species richness (number of species) recorded in the Arrombado Lake during the study period in all sampling stations. aug=August; mar= March.

Lecane proiecta was found only during flooding periods at low numbers. Synchaetidae was equally important to characterize the rotifers assemblage, especially in receding water periods in stations 2 and 3. Synchaeta oblonga, Polyarthra vulgaris and Ploesoma truncatum were very important species due to their high density values. Nonetheless, $P$. truncatum unlike the two other species mentioned, occurred only during one phase of the hydrological cycle in both years: the receding water period.

Some population shifts were remarkable. The most striking example of such shifts is the appearance of Brachionus zahniseri var. reductus only during receding periods and $B$. zahniseri restricted to flooding periods. Other species such as Lecane remanei, L. proiecta, Macrochaetus sericus, Monommata sp. and B. gillardi, also had their abundances directly linked to seasonality (Table II).
Species diversity (Shannon-Wienner) ranged from 1.1 (Station 2, flooding 2008) to 2.15 (Station 1, receding period of 2007). In general, slightly higher values occurred during receding waters of both years. On the other hand, evenness showed noticeable seasonal oscillation with highest values during receding waters and values during flooding, except in station 1 during receding waters of 2006 (Figure 5).

\section{BIOTIC AND ENVIRONMENTAL INTEGRATION}

Results of the hypothesis test showed that seasonal differences were found in the rotifer community of LARR. Rotifer richness $\left(\mathrm{P}<0.001, \mathrm{~F}_{(1,14)}=17.67\right)$, evenness $\quad\left(\mathrm{P}<0.001, \quad \mathrm{~F}_{(1,14)}=18.43\right)$, abundance $\left(\mathrm{P}=0.05, \quad \mathrm{~F}_{(1,14)}=4.03\right)$ and diversity $(\mathrm{P}=0.01$, $\left.F_{(1,14)}=7.75\right)$ were higher either during receding or flooding periods, as shown in the last section. 


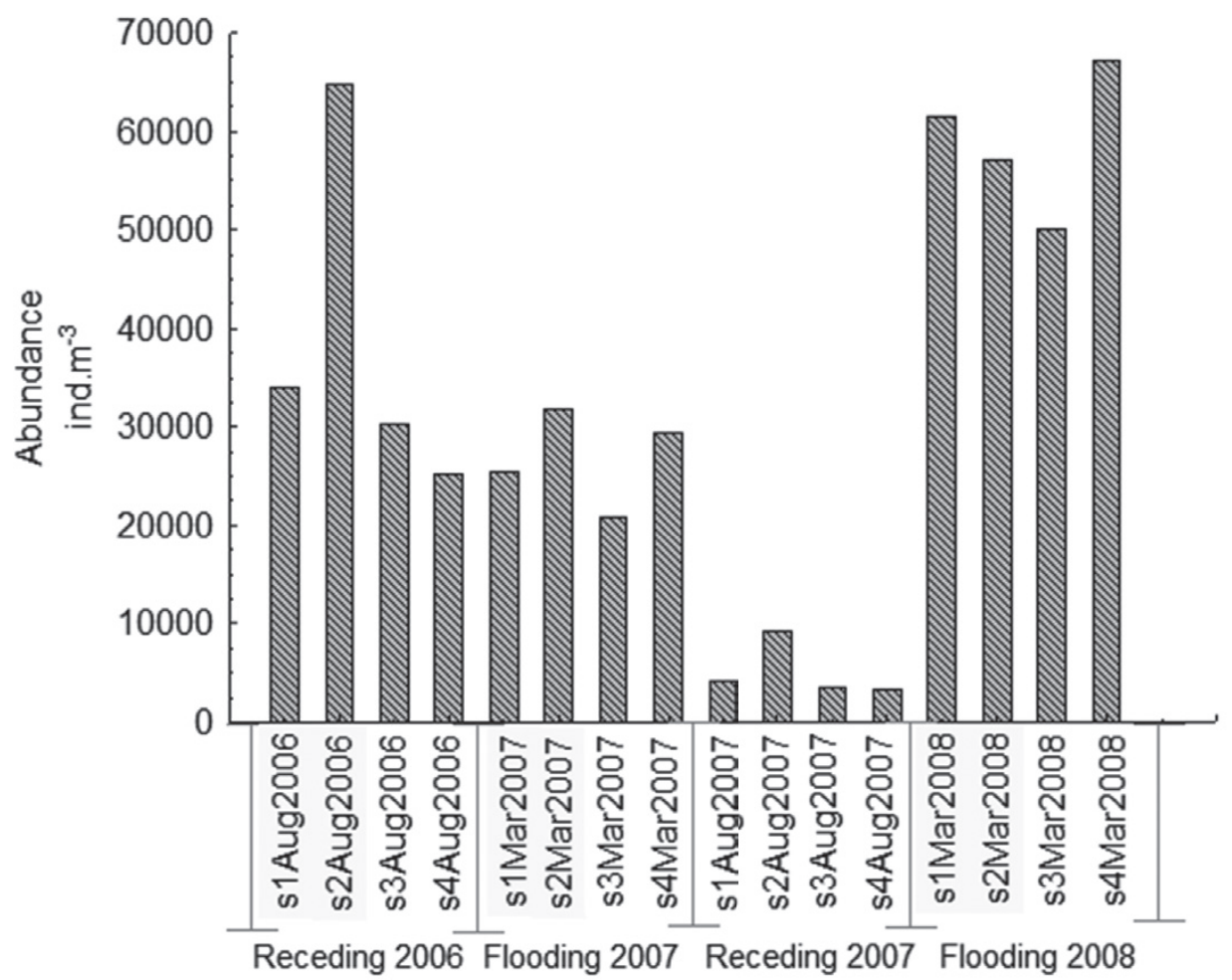

Figure 4 - Total abundance (ind. $\mathrm{m}^{-3}$ ) of rotifers during flooding (August) and receding (March) phases of two consecutive years in all the sampling stations (s1, s2, s3 and s4).

However, these response variables did not differ spatially $\left(\mathrm{P}>0.05, \mathrm{~F}_{(1,14)}=0.26\right)$ nor were affected by the interaction of seasonality and spatial distribution $\left(\mathrm{P}>0.5 ; \mathrm{F}_{(12,13.8)}=1.03\right)$.

Canonical Correspondence Analysis (CCA) indicated that the environmental variables explained $61.6 \%$ of rotifers assemblage variation among samples. The first and second axes accounted for $52.3 \%$ and $5.3 \%$ of species data variance, respectively. The canonical axis was also assessed as significant using the Monte Carlo permutation test $\left(\mathrm{P}=0.001 ; \mathrm{F}_{(3,12)}=5.782\right)$.

On the CCA triplot (Figure 6), samples and frequent species were grouped as to differences or similarities along an environmental gradient, mostly represented by axis 1 . Axis 1 of the CCA was highly influenced by electrical conductivity and Secchi disc depth values, mirroring the gradient caused by seasonality. Axis two, on the other hand, represented mostly $\mathrm{pH}$ and dissolved oxygen variations.

A clear seasonality gradient represented mostly by axis 1 can be seen by a sharp differentiation of receding (even numbers) and flooding (odd numbers) samples. Species occurrence clearly reflected these distinct hydrological periods. Thus, species which occurred only during the receding phase (such as $B$. zahniseri reductus and L. remanei) can be seen in the right half of the chart while species which occurred during flooding (such as B. zahniseri, L. proiecta, $B$. gillardi and $M$. sericus amongst others) can be observed in the left half of the chart. Additionally, frequent species throughout the entire study can also be observed, occurring in the middle of the graphic. 


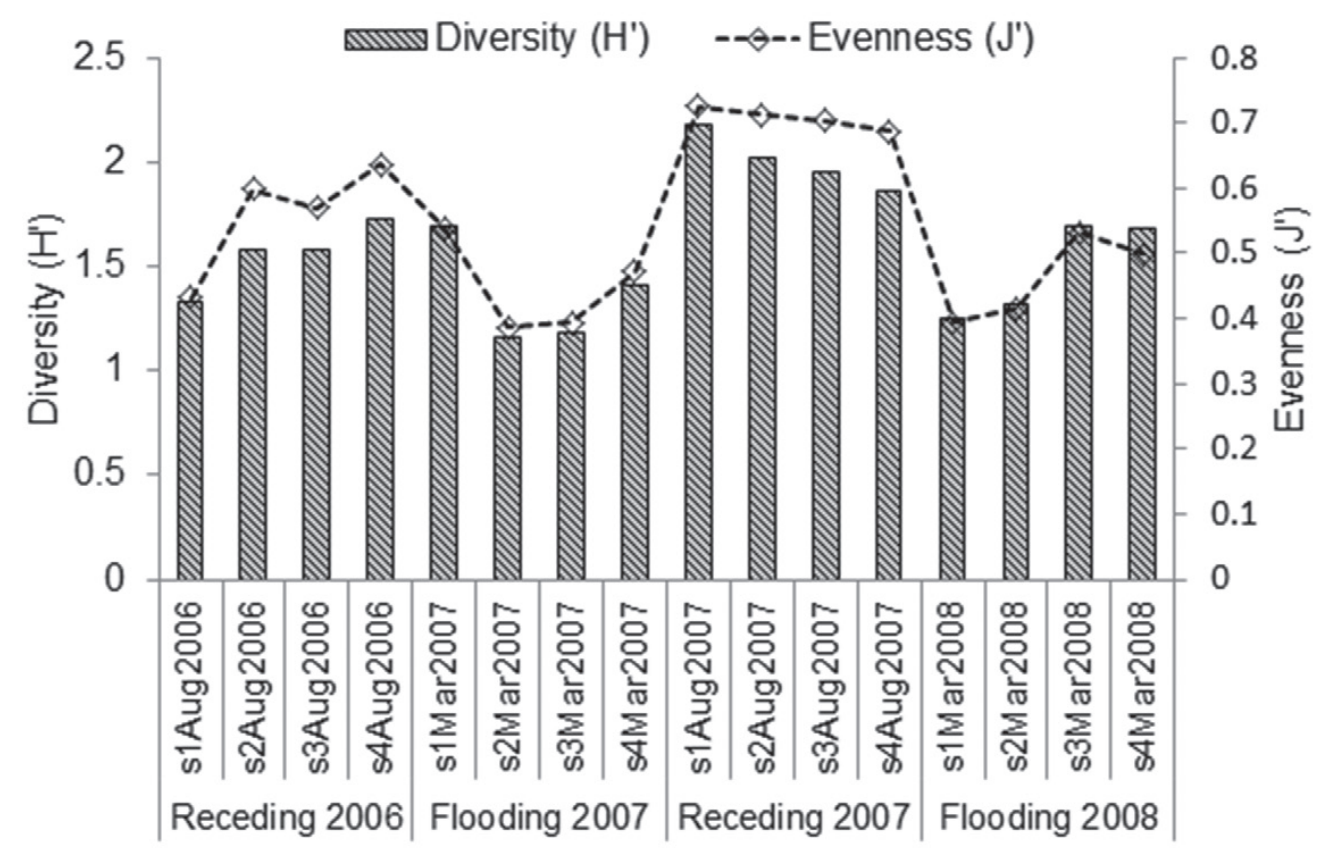

Figure 5 - Diversity (bars) and evenness (line) indexes of all sampling stations (s1, s2, s3 and s4) during the two consecutive hydrological cycles (August and March).

\section{DISCUSSION}

\section{RoTIFER SPECIES COMPOSITION AND ABUNDANCE}

Overall, our results suggest that flood events strongly influence rotifer abundance, richness and species composition through direct and indirect effects, either through the variation of physical and chemical variables, or by increasing the role of the Negro river as a source of species. Local processes, such as competition, predation, resource constraints and disturbance, mostly influence local community structure and diversity (Cottenie and Meester 2004). Thus, in our study, these local processes might be responsible for changes in species composition, together with regional processes such as dispersal - that provides movement among patches and theoretically, ongoing species turnover through extinction and recolonization (Allen et al. 2011).

Our study showed the predominance of some rotifers families, as Brachionidae, Lecanidae and
Trichocercidae, which have also been recorded throughout different studies, not only in the Amazon floodplain as in other Brazilian freshwater ecosystems (Bonecker et al. 2009, Aoyagui and Bonecker 2004, Bozelli 1992). High species richness of these three families are likely to be associated with a wide range of habitats found in the studied lake, leading to the predominance of species with different habits and niches - littoral species, pelagic and benthic.

The family Brachionidae was the most abundant and frequent taxa in our study. In this group, there was a predominance of the Brachionus genus, in which most of the littoral and pelagic species are commonly found in the warmer waters in the interior of the subtropical region (Kutikova and Fernando 1995). The species Brachiouns zahniseri and B. zahniseri var. reductus were important since they had alternating patterns in their population dynamics in relation to the flood pulses. As to this marked 


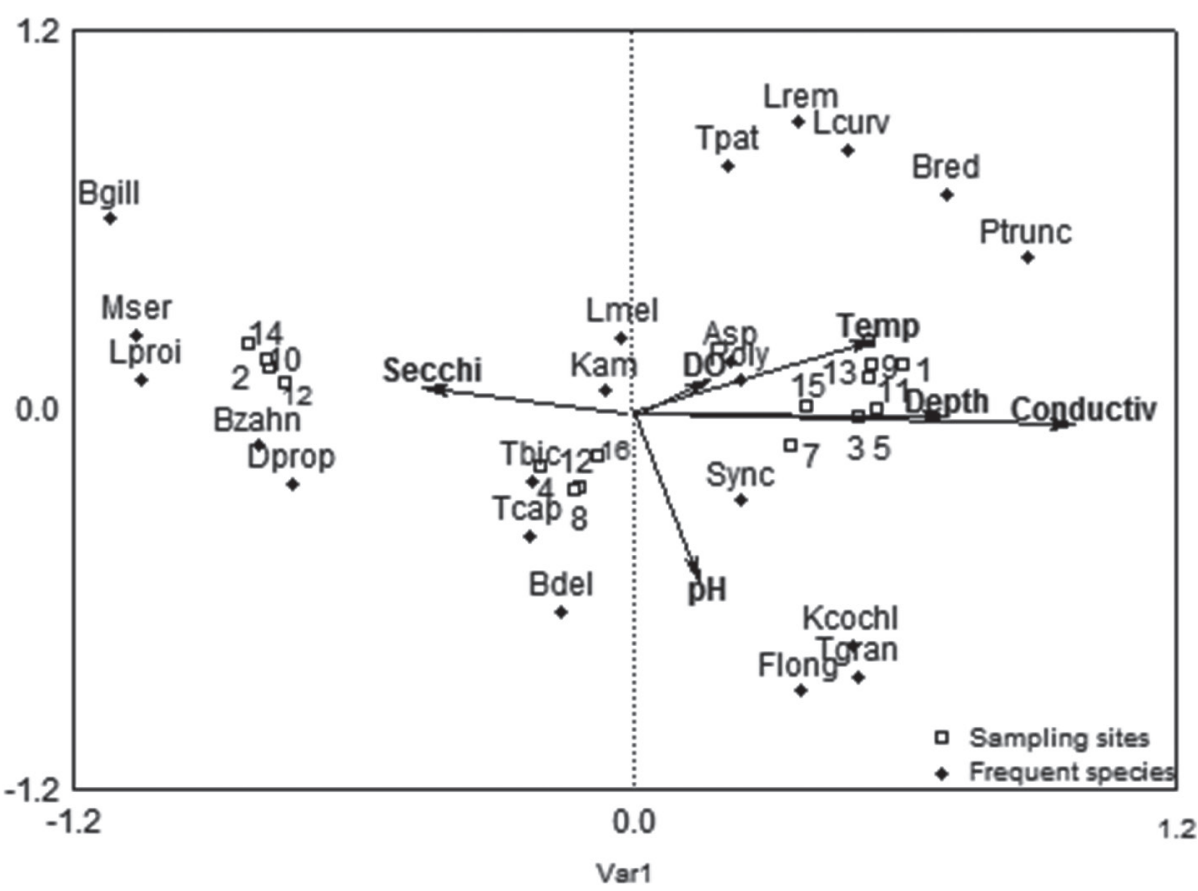

Figure 6 - CCA Ordination Diagram displaying physical and chemical variables (arrows), sampling sites $(\square)$ and frequent species occurrence $(\diamond)$. Numbers (1 to 16) read: Even numbers $=$ Flooding of 2007 and 2008; Odd numbers $=$ Receding period of 2006 and 2007; 1 to 4= Station 1; 5 to $8=$ Station 2; 9 to 12= Station3; 13 to 16= Station 4. Biotic variables read: Mser= Macrochaetus sericus; Lproi=Lecane proiecta $;$ Bgill= Brachionus gillardi; $\mathbf{D p r o p = D i p l e u c h l a n i s ~ p r o p a t u l a ; ~}$ Bzahn= Brachionus zahniseri; $\mathbf{B d e l}=$ Bdloidea; $\mathbf{T c a p}=$ Trichocerca capucina $; \mathbf{T} \mathbf{b i c}=$ Trichocerca bicristata; $\mathbf{K a m}=$ Keratella americana $; \mathbf{L m e l}=$ Lecane melini; $\mathbf{S y n c}=$ Synchaeta oblonga $; \mathbf{P o l} \mathbf{y}=$ Polyarthra sp; $\mathbf{A s p}=$ Asplancna sieboldi; $\mathbf{T}$ pat $=$ Testudinella patina $; \mathbf{L r e m}=$ Lecane remanei; $\mathbf{L} \mathbf{c u r v}=$ Lecane curvicornis; Flong= Filinia longiseta $;$ Tgran= Trichocerca similis grandis; Kcochl= Keratella cochlearis; Bred= Brachionus rzahniseri var. reductus; Ptrun= Plesoma truncatum. Physical and chemical variables: $\mathbf{S e c c h i}=$ transparency; $\mathbf{D O}=$ dissolved oxygen; $\mathbf{p H}=\mathbf{p H} ; \mathbf{D e p t h}=$ total depth; Conductiv $=$ electrical conductivity; $\mathbf{T e m p}=$ water temperature.

population shift, it's important to emphasize that in spite of being a variation of the same species, B. zahniseri var. reductus has a larger body size and longer antero-dorsal and ventral margin spines (Koste 1978). Possible explanations for such shift in species dominance are multiple: as an example, drastic changes in environmental conditions could have caused hatching of resting eggs.

Nevertheless, unfavorable conditions can on the other hand, induce the production of resting eggs by some rotifer species (Nogrady et al. 1993), such as B. zahniseri and B. zahniseri reductus. Shiel et al. (1998) also stated the importance of resting eggs for rotifer community structure, implying that, regardless of the dispersal mechanism, such strategy was clearly the source for colonization of ephemeral ponds, for example. In a study on Cristalino and TarumãMirim lakes, Hardy (1980) also indicated a shift in Brachionus genera composition from one season to another. In this study, B. zahniseri reductus had higher contribution to the abundance of rotifers during July, while B. gessneri (synonym of B. zahniseri) was mainly important in February (Hardy 1980).

In addition, intraspecific and interspecific competition amongst rotifers, for example, might help shape rotifers community structure, and might 
also be the cause for species differentiation (Snell 1978). The two different forms of the same species of B. zahniseri, could be looked upon as belonging to a partioned population, therefore competition between clones might be plausible.

In the Lecanidae family, on the other hand, we can also point out two important species: Lecane melini - which has a small range of occurrence, being found mainly in Amazonian waters and endemic of the neotropical region (Segers 2007) and Lecane remanei - first described in the waters of the Amazon (Hauer 1965, Koste 1978). L. remanei also showed patterns of change in its population, according to the flood pulses.

Lecane remanei and Brachionus gillardi were important indicators of changes in the water column. L. remanei was mostly present during receding water periods, while $B$. gillardi was restricted to flooding periods. Both species were dominant, together with B. gessneri and L. melini. In this case, changes in rotifers species dominance could also be explained by food quality and vulnerability to predation pressure by other organisms, such as, the rotifer Asplanchna sp. (Ooms-Wilms et al. 1999). Thus, interspecific competition should not be discarded specially due to differences in trade-offs between gleaner-opportunistic species in varying resources environments (Kirk 2002).

Another interesting remark, as to the rotifer composition in LARR, is the presence of Lecane proiecta in distinct phases of the flood pulse. L. proiecta is also endemic to South and Central America (Segers 2007) and has been recently found to be associated to Brazilian floodplain lakes (Bonecker et al. 2009, Joko et al. 2008). The restricted presence of $L$. proiecta, for example, in one season or another was also discussed by Ulloa (2004) who similarly found higher densities in high water seasons. On the other hand, Vásquez and Rey (1989) reported highest abundances of $L$. proiecta during the low water phase. The reason for L. proiecta population shift in our study is possibly due to the flooding of the adjacent forest, small ponds and puddles which could help with the recolonization by this species. L. proiecta is often associated with floating-grass meadows (Koste 1978). In addition, Saunders III and Lewis Jr (1988) also indicated that the abundance of L. proiecta alone could suggest that off-channel habitats were important sources for the planktonic community as a whole.

Shifts in total rotifer abundance were seen in different phases and the lowest densities were observed in the receding period of 2007. Duration and strength of the flood pulse might be good explanations as to why such shifts occurred. Some authors, however, explain highest and lowest values of zooplankton abundance based on different premises (1) either being based on the dilution effect caused by the increase in water volume in high water periods (Bozelli et al. 2000) (2) or by assuming that the progressive increase in zooplankton density - from the middle-receding all the way through early-flooding periods - could be associated to the input of nutritious substances from the flooded forest (Brandorff and Andrade 1978, Carvalho 1983).

\section{BIOTIC AND ENVIRONMENTAL INTEGRATION}

Seasonality is a main factor shaping rotifers assemblage in LARR. Such marked seasonality reflected in the studied community, is associated to the flood pulse itself. As most varzea and shallow lakes of the river-floodplain systems, LARR has an extensive variation of the water volume during hydrological cycles. These variations are caused by the flood pulse, which is the major driving force determining productivity and community structure of aquatic organisms (Junk et al. 1989). Flooding also causes cyclical changes in abiotic variables, intimately connected to rotifer assemblage variations. For instance, input of leaves and organic matter directly into the lake during flooding, associated to decomposition processes, is probably the cause for the higher values of electrical conductivity and depth 
(Thomaz et al. 1992) observed in our study in the beginning of the receding water periods, after the high water season.

Flood events also cause shifts in habitat composition and in floodplain-river systems. Thus, high diversity of habitats and species richness derived from gradients from the main channel to lateral areas, related with water current, produce a large spectrum of habitats (Roach et al. 2009). Nonetheless, Burdis and Hoxmeier (2011) specify the increase of diversity due to the presence of vegetation associated rotifers. A small spatial distinction observed in species richness - a higher number of taxa in Station 4 - could be explained by the presence of an array of habitats. Station 4 is a shallow pelagic zone influenced by the presence of a littoral zone comprised by submerged macrophytes and flooded vegetation.

Another very important feature of the studied ecosystem is the presence of humic substances, which are products of incomplete decomposition of allochtonous organic carbon. Humic substances have ecological functions mostly related to iron and phosphorus bioavailability, light penetration and most of all, pH control (Steinberg et al. 2006). Rotifers, through exhibiting a wide range of $\mathrm{pH}$ tolerance as a group (Berzins and Pejler 1987, 1989), might be indicators of $\mathrm{pH}$ variations on the water column. Some species are often associated to highly acidic environments (see review in Deneke 2000) and since this variable explained most of axis 2 of the CCA it is important to highlight its importance in shaping aquatic communities.

The influence of the hydrological regime on the composition and structure of rotifers assemblages, as well as other zooplankton groups, has also been observed in other floodplains environments (e.g. Lansac-Tôha et al. 1992, Bonecker et al. 2009, Paggi and José de Paggi 1990, José de Paggi et al. 2012, Koste and Robertson 1983, Bozelli 1992, Saunders III and Lewis Jr 1989). Lansac-Tôha et al. (2009) argued that the increase of habitat connectivity shaped rotifers communities as an indirect effect of seasonality, and Keppeler and Hardy (2004) found correlations between eletrical conductivity and rotifers abundance, as did we. Those studies restate the importance of seasonality and the flood pulse and invite us to search for patterns in these alluvial environments to further understand ecosystem functioning and structure, especially concerning their trophic relations and nutrient cycling.

In a nutshell, the flood pulse was also the main factor structuring the rotifers assemblage mainly through alterations in the electrical conductivity and water transparency between receding and flooding phases. Shifts in species dominance, diversity increase and abundance increment in the rotifer assemblage depicted the changes caused by water level fluctuation, either directly or indirectly.

\section{ACKNOWLEDGMENTS}

The authors thank the financial support of Petrobras (Project Bioindicadores - Plâncton e Necton como Bioindicadores Aplicados à Indústria de Petróleo) and Conselho Nacional de Desenvolvimento Científico e Tecnológico (CNPq/PIBIC - scholarship to C. Casa Nova)

\section{RESUMO}

Os rotíferos têm sido utilizados com indicadores de mudanças súbitas de características físicas e químicas do ambiente aquático. Tais características sofrem grandes variações durante o pulso de inundação em pequenos lagos associados a planícies de inundação. No entanto, poucos estudos investigam quais são as consequências deste pulso de inundação sobre a composição, abundância, riqueza e diversidade de rotíferos, especialmente em lagos amazônicos. Neste estudo, foram analisadas amostras de um pequeno lago de águas escuras de um igarapé conectado permanentemente com o rio Negro, na Amazônia Central. As amostras foram coletadas duas vezes por ano durante dois anos, compreendendo os períodos de enchente e vazante do pulso. A abundância de rotíferos aumentou 
significantemente após eventos de seca e a condutividade elétrica e a turbidez foram intrinsecamente relacionadas a esta variação. A composição de espécies também variou entre os períodos de enchente e vazante. Alguns táxons, como Brachionus zahniseri reductus e Lecane remanei foram restritos a períodos de vazante, enquanto B. zahniseri, B. gillardi e L. proiecta foram presentes apenas durante fases de enchente. Uma mudança na composição de famílias de rotíferos foi observada entre um período e outro, ilustrando o efeito de renovação de águas do pulso de inundação. Estes resultados sugerem que o pulso de inundação age como força direcionada e condição estressante que altera consideravelmente a dinâmica da comunidade de rotíferos, seja modificando a composição de espécies ou diminuindo sua abundância.

Palavras-chave: planície de inundação, pulso de inundação, igarapé, Rotifera, zooplâncton.

\section{REFERENCES}

ALlen M, VANDYKe J AND CÁCERES C. 2011. Metacommunity assembly and sorting in newly formed lake communities. Ecology 92: 269-275.

AOYAGUI ASM AND BONECKER CC. 2004. Rotifers in different environments of the Upper Paraná River floodplain (Brazil): richness, abundance and the relationship with connectivity. Hydrobiologia 522: 281-290.

ARRINGTON DA AND WINEMILLER KO. 2006. Habitat affinity, the seasonal flood pulse, and community assembly in the littoral zone of a Neotropical floodplain river. J North Am Benthol Soc 25: 126-141.

BERZINS B AND PEJLER B. 1987. Rotifer occurrence in relation to $\mathrm{pH}$. Hydrobiologia 116: 107-116.

BERZINS B AND PEJLER B. 1989. Rotifer occurrence in relation to oxygen content. Hydrobiologia 183: 165-172.

Bonecker C, AOYAGUI A AND SANTOS R. 2009. The impact of impoundment on the rotifer communities in two tropical floodplain environments: interannual pulse variations. Brazilian J Biol 69: 529-537.

BOZELLI RL. 1992. Composition of the zooplankton community of Batata and Mussurá Lakes and of the Trombetas River, State of Pará, Brazil. Amazoniana 12: 239-261.

BozelLi RL, EsTEVES FA AND RoLLAND F. 2000. Lago batata: impacto e recuperação de um ecossistema amazônico. IB/ UFRJ/SBL, Rio de Janeiro.

Branco CWC, BALTAZAR ICL, Gomara G, PINTO G AND FILLIPO R. 2002. Limnological features of Funil Reservoir (RJ, Brazil) and indicator properties of rotifers and cladocerans of the zooplankton community. Lakes Reserv Res Manag 7: 87-92.
BRANCO CWC, ESTEVES FA AND KOZLOWSKI-SUZUKI B. 2000. The zooplankton and other limnological features of a humic coastal lagoon (Lagoa Comprida, Macaé, R.J.) in Brazil. Hydrobiologia 437: 71-80.

BRANCO CWC, KOWSLOWSKI-SUZUKI B AND DEPAGGI SJ. 2005. Rotifers from a humic coastal lagoon of Rio de Janeiro State, Brazil. Stud Neotrop fauna Environ 4: 255-265.

BRANDORFF G-O AND ANDRADE ER. 1978. The relations between the water level of the Amazon River and the fate of the zooplankton population in Lago Jacaretinga, a varzea in the Central Amazon. Stud Neotrop Fauna \& Environ 13: 63-70.

BRANDORFF G-O AND HARDY ER. 2009. Crustacean os Lago Tupé, a neotropical black water lake in the Central Amazon. In: Biotupé Meio físico, Divers. Biológica e Sociocult. do Baixo Rio Negro. Amaz Cent 2: 38-52.

BURDIS RM AND HOXMEIER RJH. 2011. Seasonal zooplankton dynamics in main channel and backwater habitats of the Upper Mississippi River. Hydrobiologia 667: 69-87.

CARvalho ML. 1983. Efeitos da flutuação do nível da água sobre a densidade e composição do zooplâncton em um lago de várzea da Amazônia, Brasil. Acta Amaz 13: 715-724.

CARVAlho P ET AL. 2001. Comparative limnology of South American floodplain lakes and lagoons. Acta Sci Mar 23: 265-273.

CotTenIE K AND MEester LD. 2004. Metacommunity structure: synergy of biotic interactions as selective agents and dispersal as fuel. Ecology 85: 114-119.

DENEKE R. 2000. Review of rotifers and crustaceans in highly acidic environments of $\mathrm{pH}$ values $>3$. Hydrobiologia 433: $167-172$.

FERNANDO CH. 2002. A guide to tropical freshwater zooplankton. Leiden: Backhuys Publishers, 291 p.

HARDY ER. 1980. Composição do zooplâncton em cinco lagos da Amazônia Central. Acta Amaz 10: 557-609.

HARDY ER, RoBERTSON BA AND Koste W. 1984. About the relationship between the zooplankton and fluctuating water levels of Lago Camaleão, a Central Amazonian várzea lake. Amazoniana 9: 43-52.

HAUER J. 1965. Zur Rotatorienfauna des Amazonasgebietes. Int Rer Ges Hydrobiol 50: 341-389.

JEPPESEN E ET AL. 2011. Zooplankton as indicators in lakes: a scientific-based plea for including zooplankton in the ecological quality assessment of lakes according to the European Water Framework Directive (WFD). Hydrobiologia 676: 279-297.

Joko CY, LANSAC-TÔHA FA, AKANE E AND BONECKER CC. 2008. Novas ocorrências de Lecane no plâncton de distintos ambientes da inundação planície de inundação do alto rio Paraná. Acta Sci Biol Sci 30: 165-171.

JosÉ DE PAGGI S ET AL. 2012. Horizontal distribution of rotifers in a subtropical shallow lake (Paraná floodplain, Argentina). Fundam Appl Limnol / Arch für Hydrobiol 180: 321-333.

JUNK WJ ETAL. 1989. The flood pulse concept in river-floodplain systems. Can Spec Publ Fish Aquat Sci 106: 110-127.

KIRK KL. 2002. Competition in variable environments: experiments with planktonic rotifers. Freshwater Biol 47: 1089-1096. 
Koste W. 1978. Rotatoria: Die Rädertiere Mitteleuropas. Berlin: Gebrüder Borntraeger, 673 p.

Koste W And RoBertson B. 1983. Taxonomic studies of the Rotifera (Phylum Aschelminthes) from a Central Amazonian várzea lake, Lago Camaleão (Ilha Machantaria, Rio Solimões, Amazonas, Brazil). Amazoniana 8: 225-254.

KUCZYNSKI D. 1987. The rotifer fauna of Argentine Patagonia as a potential indicator. Hydrobiologia 150: 3-10.

KutikOva LA AND Fernando CH. 1995. Brachionus calyciflorus Pallas (Rotatoria) in inland tropical latitudes. Int Rer Ges Hydrobiol 80: 429-441.

LANSAC-TÔHA FA ET AL. 2009. Biodiversity of zooplankton communities in the Upper Paraná River floodplain: interannual variation from long-term studies. Braz J Biol 69: 539-549.

LANSAC-TÔHA FA, LIMA AF, THOMAZ SM AND ROBERTO MC. 1992. Zooplâncton de uma planície de inundação do rio Paraná. I. Análise qualitativa e estrutura da comunidade. Rev Unimar 14: 35-55.

Nogrady T, Wallace RL and SNell TW. 1993. Rotifera. Volume 1: Biology, Ecology and Systematics. The Hague: SPB Academic Publishing bv, 299 p.

Ooms-Wilms A, Postema G AND Gulati R. 1999. Population dynamics of planktonic rotifers in Lake Loosdrecht, the Netherlands, in relation to their potential food and predators. Freshwater Biol 42: 77-97.

PAGgi JC AND José DE PAGgI S. 1990. Zooplâncton de ambientes lóticos e lênticos do rio Paraná médio. Acta Limnol Bras 3: 685-719.

PAIDERE J. 2009. Influence of flooding frequency on zooplankton in the floodplain of the Daugava River (Latvia). Acta Zool lituânica 19: 306-313.

ROACH KA, THORP JH AND DELONG MD. 2009. Influence of lateral gradients of hydrologic connectivity on trophic positions of fishes in the Upper Mississippi River. Freshwater Biol 54: 607-620.

RODRÍGUEZ M AND LEWIS JR WL. 1994. Regulation and stability in fish assemblages of neotropical floodplain lakes. Oecologia 99: 166-180.

RODRÍGUEZ M AND LEWIS JR WL. 1997. Structure of fish assemblages along environmental gradients in floodplain lakes of the Orinoco River. Ecolo Monogr 67: 109-128.
SAUNDERS III J AND LEWIS JR WL. 1988. Zooplankton abundance and transport in a tropical white-water river. Hydrobiologia 162: 147-155.

SAUNDERS III J AND LEWIS JR WM. 1989. Zooplankton abundance in the lower Orinoco River, Venezuela. Limnol Oceanogr 34: 397-409.

SEGERS H. 2007. Global diversity of rotifers (Rotifera) in freshwater. Hydrobiologia 595: 49-59.

SHIEL RJ, GREEN JD AND NIELSEN DL. 1998. Floodplain biodiversity: why are there so many species? Hydrobiologia 387: 39-46.

Sioli H. 1975. Tropical River: The Amazon. In: River Ecol. Whitton BA (Ed). Berkley: U.C Press, p. 461-487.

SNELL TW. 1978. Intraspecific competition and population structure in rotifers. Ecology 60: 494-502.

Souza LCE, Branco CWC, Domingos P AND Bonecker SLC. 2011. Zooplankton of an urban coastal lagoon: composition and association with environmental factors and summer fish kill. Rev Bras Zool 28: 1-8.

STEINBERG CEW ET AL. 2006. Dissolved humic substances - ecological driving forces from the individual to the ecosystem level? Freswhater Biol 51: 1189-1210.

THOMAZ SM, LANSAC-TÔHA FA, ROBERTO MC AND EsTEVES FA. 1992. Seasonal variation of some limnological factors of lagoa do Guaraná, a varzea lake of the High Rio Paraná, State of Mato Grosso do Sul, Brazil. Rev Hydrobiol Trop 25: $269-276$

UlloA V. 2004. Density and biomass of planktonic rotifers in different habitats in upper Parana River (PR, Brazil). Acta Limnol Bras 16: 281-292.

VÁSQUEZ E AND REY J. 1989. A longitudinal study of zooplankton along the Lower Orinoco River and its Delta (Venezuela). Ann Limnol 25: 107-120.

WALKER KF. 1981. A synopsis of ecological information on the saline lake rotifer Brachionus plicatilis Müller 1786. Hydrobiologia 81: 159-167.

Walsh EJ, Salazar M, Remirez J, Moldes O AND Wallace RL. 2006. Predation by invertebrate predators on the colonial rotifer Sinantherina socialis. Invertebr Biol 125: 325-335. 